INSIGHTS INTO REGIONAL DEVELOPMENT

ISSN 2669-0195 (online) http://jssidoi.org/IRD/ 2019 Volume 1 Number 3 (September) http://doi.org/10.9770/IRD.2019.1.3(4)

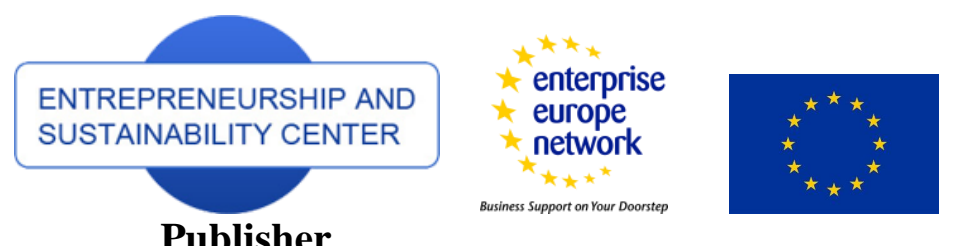

http://jssidoi.org/esc/home

\title{
PERFORMANCE OF CLUSTERS IN MOROCCO IN THE SHIFTING ECONOMIC AND INDUSTRIAL REFORMS*
}

\section{Boumediene Amraoui ${ }^{1}$, Abdesselam Ouhajjou², Salvatore Monni ${ }^{3}$, Najiba El Amrani El Idrissi ${ }^{4}$, Manuela Tvaronavičiené ${ }^{5}$}

\author{
${ }^{1,2}$ Faculty of Juridical, Economic and Social Sciences of Fez, University Sidi Mohammed Ben Abdallah, Fes, Morocco \\ ${ }^{3}$ Department of Economics, Roma Tre University, Via Silvio D'amico 77, Rome 00145, Italy \\ ${ }^{4}$ Faculty of Science and Technology, University Sidi Mohamed Ben Abdellah, Fez, Morocco \\ ${ }^{5}$ Vilnius Gediminas Technical University, Saulètekio 11, Lt-10223 Vilnius, Lithuania
}

E-mail: Corresponding author: Boumediene Amraoui, boumediene.amraoui@usmba.ac.ma

Received 3 May 2019; accepted 20 June 2019; published 30 September 2019

\begin{abstract}
The emergence of cluster policy around the world is inspired by the models of the Silicon Valley. Territorial and local development productive systems depend on the new integrated management models that are clusters. Morocco has adopted economic and industrial reforms aimed at accelerating the structural transformation of its production system by strengthening its territorial development model while adopting a cluster development policy through the National Pact for Industrial Emergence, but the performance of these clusters is questionable because they are in the genesis stage and must overcome social, managerial, financial and administrative obstacles and lack of public and private sector partnerships and insufficient innovative collaborative projects. This raises the question of measuring the dynamics and performance of a clusters and the problem of evaluating the economic development of a region. In this study, we intend to conduct review of Moroccan clusters and diagnose their performance in the context economic and industrial moving.
\end{abstract}

*This research was supported by the projects, which have received funding from the European Union: International Research Staff Exchange Scheme (IRSES) FP7-PEOPLE-2012-IRSES, Grant Agreement Number 319017 SHuMED and ES H2020MSCA-RISE-2014 CLUSDEVMED Grant Agreement Number 645730730
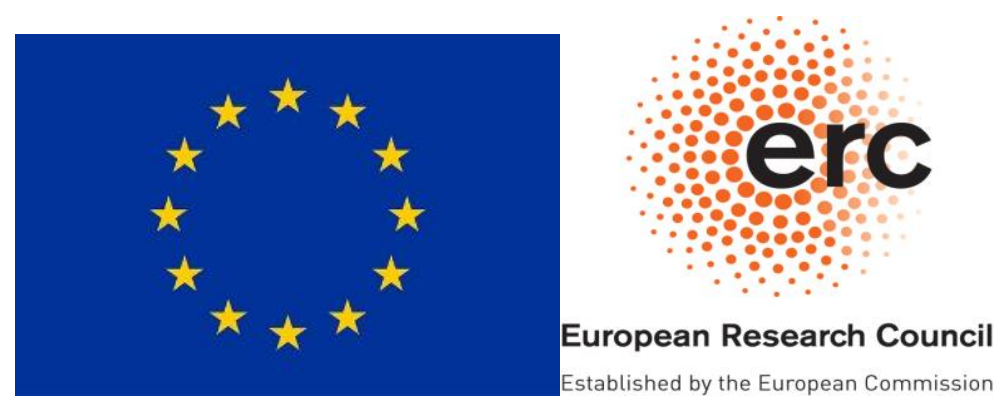


\section{INSIGHTS INTO REGIONAL DEVELOPMENT}

ISSN 2669-0195 (online) http://jssidoi.org/jesi/

2019 Volume 1 Number 2 (September)

http://doi.org/10.9770/IRD.2019.1.3(4)

Keywords: The Moroccan industrial strategies; economic reforms and industrial development; development of clusters; the performance of clusters

Reference to this paper should be made as follows: Amraoui, B.; Ouhajjou, A.; Monni, S.; El Amrani El Idrissi, N.; Tvaronavičienė, M. 2019. Performance of clusters in Morocco in the shifting economic and industrial reforms, Insights into Regional Development 1(3): 227243. https://doi.org/10.9770/ird.2019.1.3(4)

JEL Classification: O55

\section{Introduction}

Conventional factors of territorial development such as proximity to natural resources, production units and skilled population are not currently able to ensure sustainable industrial growth (Porter, 1990). This is due to the fact that the mechanisms of local development do not correspond to territorial productive systems, which are considered by the majority of researchers and decision-makers to be self-evident (Torre, Zimmermann, 2015). To achieve an advantageous competitive capacity there is currently a trend towards integrated management systems, namely clusters. The latters group companies into more innovative and competitive "clusters" (Porter, 1998). The countries of the North quickly placed these clusters in their industrial policies (Pommier, 2014).

Porter (1990) firstly has defined the cluster as a geographic concentration of interconnected firms, suppliers, service providers, related industry firms and associated institutions (universities, standardization agencies or professional organizations) that compete and cooperate. In a second time Porter (1998) emphasized the capacity of creation and innovation of clusters via the division of labour between companies having regional proximity. According to Delgado et al. (2014) clusters are geographical concentrations of industries linked by knowledge, skills, inputs, demand and/or other links. According to E. Gallié et al. (2014), the emergence of cluster policy around the world is inspired by the models of the Silicon Valley cited by Porter $(1990,1998)$ and other researches show their beneficial effects on economic efficiency of the firms and territories on which they are located. Industrial clusters act as instruments to reinforce the innovation capacities of companies (Tvaronavičienè et al., 2015; Monni et al., 2017; Zemlickiene et al., 2017; Žižka et al., 2018; Petrenko et al., 2019).

According to P. Parto (2008) a cluster is a group of interdependent companies that innovate and generate economic growth. A fundamental element of clustering is the synergy created by complementarities and the dissemination of knowledge among cluster members. These synergies can be called collective efficiency (Carpinetti et al., 2007; Yang, Černevičiūtè, 2017; Tvaronavičienè, Razminienè, 2017).

The success of a cluster is positively influenced by the variety and complementarity of the activities of the firms (Staber, 2001). For E. Callegati, S. Grandi (2007), the dynamics of cluster require a combination of competition and cooperation between companies, on the one hand competition as a powerful incentive for innovation and increased efficiency, and on the other hand cooperation that promotes the spread of knowledge and the overall attractiveness of the system.

Before integrating cluster structures as a means of territorial development, Morocco has established economic social reforms: National Initiative for Human Development (NIHD), Green Morocco Plan, National Pact for Industrial Emergence Industrial Acceleration Plan (IAP) aimed at accelerating the structural transformation of its productive system and making it more competitive. (Ministry of Economy and Finance of Morocco, 2018)

In addition, the competitiveness of the Moroccan industrial sector is confronted with several entrepreneurial and technological constraints, particularly in the case of SMEs (eng. Small and medium-sized enterprises) which represent $94 \%$ of the Moroccan industrial fabric, the measures envisaged in the framework of the Industrial 


\section{INSIGHTS INTO REGIONAL DEVELOPMENT}

ISSN 2669-0195 (online) http://jssidoi.org/jesi/

2019 Volume 1 Number 2 (September)

http://doi.org/10.9770/IRD.2019.1.3(4)

Acceleration Plan should nevertheless, unleashing the potential of the Moroccan industrial sector and turning it into a real lever for structural transformation of the Moroccan economy. The Industrial Acceleration Plan (IAP) and the "clusters", expressions of a spatial anatomy testifying to the new dynamism of this cosmopolitan country (Eddellani et al., 2019). In this respect, as early as the 2000s, Morocco entered for the first time into cluster development policy through the National Pact for Industrial Emergence (fr. Pacte National pour l'Emergence Industrielle). Today, Morocco's cluster program includes the "Morocco Innovation Strategy", which aims to improve $R \& D$ and promote innovation. The aim was to develop 15 national clusters from 2009 . The objective is to reinforce the coherence of its development model and make it more inclusive, especially at the territorial level by placing the regions of the Kingdom in the rank of development actors and prepare a space for wealth creation and emergence of competitive specialization profiles. Additionally, Morocco actively pursues an industrial policy plan (fr. Plan d'Accélération Industrielle) until 2020 which includes the development of cluster organisations and cluster policy. The program clustering combines a top-down and bottom-up approach: public support and at the same time launching a competition between clusters. Other cluster organizations are promoted by other stakeholders such as the solar cluster or the industrial sector of environmental services (CISE). The development of the attractiveness of the twelve regions of Morocco for industrial investments should promote a distribution more equitable and sustainable wealth at the national level (Ministry of Economy and Finance of Morocco, 2018).

The question about the effectiveness of clusters was discussed in a context of comparative study in Europe the existence of two ideal-typical models Gallié et al. (2014). Cluster approaches and methods of analysis (Tvaronavičienè et al., 2015). Cluster effectiveness through comparative analysis (Tvaronavičienė et al., 2015) and clusters to local industrial ecosystems (Torre, Zimmermann, 2015).

In Morocco, the emergence of clusters created new forms of regionalised production as a special Moroccan model in the gestation (Eddellani et al., 2019), which tends towards a specific Maghrebian model (Pommier, 2014) and is characterized by the emergence of a new territorial industrial policy (Rajae A, 2016), a tourism cluster in Morocco (Porter et al., 2008) and to what extent these Moroccan clusters are performing well (El Waatmani, Makhtari, 2019).

This study aims to detect indicators for evaluation performance of Moroccan clusters and highlight the economic impact on their host territories. This raises the question of measuring the dynamics and performance of a cluster in innovation and the problem of evaluating the economic development of a region. In this study, we intend to conduct an environmental scan of Moroccan clusters and diagnose their performance in the moving of economic and industrial context. This article is divided into four sections: 1) economic reforms and industrial development; 2) elaboration of the three Moroccan industrial strategies; 3) cluster development in Morocco; 4) the performance of clusters and their impacts on regional development.

\section{Economic reforms and industrial development}

Morocco undertook economic and industrial reforms through the privatization program in 1993 followed by structural reforms in 1995 with the aim of strengthening the economy, guiding industrial development and boosting the country's competitiveness. According to the Office of the High Commission for Planning (HCP) (2009) the reforms have mainly affected the liberalization of foreign trade, the deregulation of prices, the opening of the national economy to foreign investors, the modernization of the tax system, the restructuring of state-owned enterprises and modernization of the capital market. It was signed more than 30 sectoral program contracts at the national level, 16 regional plan contracts under the Green Morocco Plan, more than 15 delegated management contracts and 28 cities contracted delegated management contracts. In addition to the creation of institutions of mixed economy and institutions with a funding role such as the Hassan II Fund for Economic and Social Development (2000). In the role of promoting investment in the economic and social sectors, the Agency of Agricultural Development (ADA), public institution, its role implementing the Green Morocco Plan, Deposit 


\section{INSIGHTS INTO REGIONAL DEVELOPMENT}

ISSN 2669-0195 (online) http://jssidoi.org/jesi/ 2019 Volume 1 Number 2 (September) http://doi.org/10.9770/IRD.2019.1.3(4)

Caisse and Management of Morocco (Caisse de Dépôt et de gestion du Maroc) (CDG), the National Company of Motorways of Morocco (ADM), Holding Company Al Omrane and subsidiaries, National Agency for the Promotion of Small and Medium Enterprise (ANPME): Instituted to contribute to the development and upgrading of the company. Regarding the regional development poles, three development agencies have been created: the Agency for the Development of the Southern Provinces (2002), the Agency for the Development of the Provinces of the Oriental (2006) and the Agency for the Development of Northern Provinces (1996) plus 16 Regional Investment Centre's (RICs). In addition, the Moroccan economy has undergone a structural change, with economic growth rising from 3,8\% between 1999-2003 to 4,8\% between 2004 and 2008. This new level of growth was due to the structural transformation of the productive fabric (service activities), the share of tertiary activities in total real value added increased from 52,1\% to 56,4\% between 1998 and 2008, while secondary activities experienced a virtual stagnation of their weight in the total real value added to $27,5 \%$ in 2008 after $27,7 \%$ in 1998 . The value added of the primary sector (agriculture and fisheries), it decreased by $20,2 \%$ of the GDP in 1998 to $16,1 \%$ in 2008. This economic growth is due to reforms affecting all sectors, industry, agriculture, PTB and trade and each sector has its part of GDP contribution as shown in Table 1 below.

Table 1. The distribution of GDP by sectors.

\begin{tabular}{|c|c|c|c|c|c|c|c|c|c|c|c|c|c|c|c|c|c|c|c|}
\hline $\begin{array}{l}\text { Distribution of } \\
\text { GDP by sector } \\
\text { of activity } \\
\text { (in \%) }\end{array}$ & $\stackrel{\infty}{\sigma}$ & बे & ڤ్రి & $\overline{\mathrm{N}}$ & 气ิે & 气ิ & ث্̀े & 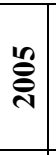 & ڤે̊ి & 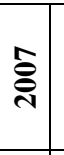 & 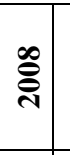 & ڤ્̀े & $\stackrel{\overbrace{}}{\bar{~}}$ & $\overline{\overline{\mathrm{N}}}$ & 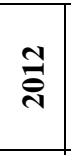 & $\stackrel{m}{\bar{\sim}}$ & $\stackrel{ \pm}{\vec{\sim}}$ & $\stackrel{n}{\bar{\sim}}$ & 롤 \\
\hline & $\begin{array}{l}n \\
\vdots \\
=\end{array}$ & $\begin{array}{l}n \\
n\end{array}$ & $\stackrel{m}{\stackrel{2}{2}}$ & 芒 & 热 & $\begin{array}{l}n \\
n\end{array}$ & $\stackrel{-}{ \pm}$ & $\stackrel{3}{2}$ & $\begin{array}{l}n \\
n\end{array}$ & 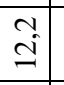 & $\stackrel{2}{2}$ & $\stackrel{n}{2}$ & 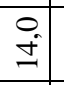 & 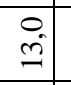 & $\stackrel{n}{2}$ & & & & $\begin{array}{l}n \\
\dot{I}\end{array}$ \\
\hline & $\begin{array}{l}\infty \\
\stackrel{1}{0}\end{array}$ & $\frac{m}{\sim}$ & $\stackrel{m}{\vec{v}}$ & $\begin{array}{l}0 \\
\stackrel{2}{2}\end{array}$ & $\stackrel{\vec{\sigma}}{\circ}$ & $\hat{\sigma}$ & 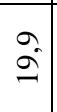 & $\stackrel{\vec{\sigma}}{\stackrel{2}{2}}$ & $\hat{\infty}$ & $\vec{\infty}$ & $\overrightarrow{\vec{i}}$ & $\ddot{\imath}$ & 2 & $\stackrel{2}{2}$ & ஜิ & $\tilde{\tilde{N}}$ & 2 & $\stackrel{2}{2}$ & $\begin{array}{l}n \\
2\end{array}$ \\
\hline & $\begin{array}{l}\infty \\
\oplus\end{array}$ & $\hat{m}$ & $\begin{array}{l}n \\
+\end{array}$ & $\stackrel{\vartheta}{\vec{\nabla}}$ & $\begin{array}{l}\hat{\sigma}^{\prime} \\
\text {. }\end{array}$ & $\vec{n}$ & $\hat{n}$ & 0 & $\hat{n}$ & $\begin{array}{l}0 \\
0 \\
0\end{array}$ & $\begin{array}{l}0 \\
\text { in }\end{array}$ & $\begin{array}{l}\infty \\
i\end{array}$ & $\begin{array}{l}0 \\
i\end{array}$ & $\begin{array}{l}n \\
n \\
n\end{array}$ & $n$ & $n$ & $\stackrel{t}{i}$ & $\begin{array}{l}\text { r. } \\
\text { n' }\end{array}$ & in \\
\hline Services & $\begin{array}{l}\dot{0} \\
\dot{n}\end{array}$ & $\begin{array}{l}n \\
\hat{n}\end{array}$ & $\begin{array}{l}\stackrel{y}{n} \\
\dot{n}\end{array}$ & $\begin{array}{l}0 \\
\dot{f} \\
i n\end{array}$ & $\vec{f}$ & $\begin{array}{l}n \\
\tilde{n}\end{array}$ & $\begin{array}{l}\infty \\
\infty \\
\end{array}$ & $\begin{array}{l}0 \\
i n \\
n\end{array}$ & $\begin{array}{l}0 \\
\dot{1} \\
\dot{n}\end{array}$ & $\begin{array}{l}n \\
\tilde{n} \\
n \\
n\end{array}$ & $\stackrel{n}{i n}$ & $\frac{n}{n}$ & $\begin{array}{l}0 \\
\dot{n}\end{array}$ & $\begin{array}{c}\overrightarrow{1} \\
\text { in }\end{array}$ & $\begin{array}{l}n \\
\tilde{n} \\
n\end{array}$ & & $\vec{i}$ & $\overline{\hat{q}}$ & \\
\hline
\end{tabular}

Source: High Commission for Planning (HCP) (2009)

Indeed, we analyse both (Table 1) Note that, during the period 2002-2016 the share of the industry to the contribution in GDP is on average of $18 \%$. The agriculture was $13,4 \%$, a regression of 3,2\% compared to the decade previous, the share of trade in GDP, it amounted to 9,85\% and the share of the construction sector in GDP, it reached $5,77 \%$ with an increase of $1,8 \%$. The 2000 s were marked by a gradual transformation of the Moroccan industry into traditional sectors, new emerging specializations in this case the automotive and aerospace industries.

This structural change is perceptible on the basis of three important variables namely exports, decent employment and foreign direct investment (FDI): Exports of the world trades in Morocco (WTM) reached, in fact, nearly 119 billion dirhams (11010 571 925,50 Euro) in 2014 against nearly 75.5 billion dirhams (6 987181052,20 Euro) in 2008, which corresponds to an additional of more than 44 billion dirhams (4 071999 553,60 Euro). This dynamic was mainly driven by the outstanding performance of the automotive sector (an average annual growth of $22 \%$ between 2008 and 2014), aeronautics (an average annual growth of $13 \%$ against $+5 \%$ for and $+4,5 \%$ for electronics). Positive evolution of the technological content of exports of manufactured products with high and medium high technology. Their part has significantly increased in recent years to $47 \%$ in 2013 against $31 \%$ in 2003 converging gradually to the global average of 56,8\% over the period 2009-2012. This trend is mainly due to the increase in exports of vehicles, electrical appliances. 


\section{INSIGHTS INTO REGIONAL DEVELOPMENT}

ISSN 2669-0195 (online) http://jssidoi.org/jesi/

2019 Volume 1 Number 2 (September)

http://doi.org/10.9770/IRD.2019.1.3(4)

Similarly, the contribution to skilled employment marks this modernization, with average annual growth rates of $16 \%, 14 \%$ and 9\% respectively for the automotive, aeronautics and electronics sectors between 2008 and 2012. These performances, however, contrast with the structural decline in formal employment in the textile and clothing industry. The analysis of the structure of the FDI shows a shift towards the industrial activities which occupied during the 2012-2014 period the first place with an average share of $30 \%$ to the detriment of the traditionally dominant activities like the real estate and the tourism (Ministry of Economy and Finance of Morocco, 2015).

In this movement of sectoral and structural reforms, whose public authorities are committed to ensuring a strong, sustainable and wealth-generating economic growth, have emerged the strategy of public-private partnership and the three industrial strategies: The (Morocco 2020 emergence plan) in 2005, the (national pact for industrial emergence) in 2009, and the (industrial acceleration plan) in 2014 (Ministry of Industry, Trade, Investment and Digital Economy of Morocco, 2016).

\section{Elaboration of the three Moroccan industrial strategies}

\subsection{Morocco 2020 Industrial Emergence Plan}

The Morocco 2020 Industrial Emergence Plan is a program to amplify Morocco's industrial development strategy through a public-private partnership (Ministry of Foreign Affairs and International Cooperation, 2019). This program, launched on December 21, 2005, creates a development framework encompassing all industrial activities, including business activities. Offshoring, this plan aims to create 440000 jobs, thereby increasing gross domestic product (GDP) by 1.6 points per year.

The objective is to strengthen the competitiveness of the industrial sector, the Emergence plan was based on three main ideas: focus industrial recovery efforts on the sectors for which Morocco has competitive advantages designated "World Trades of Morocco", in particular, Offshoring, automotive, aeronautics and space, textiles and leather, electronics and food processing, through dedicated development programs; four major Transversal Works, divided into a project to strengthen the competitiveness of SMEs, an improvement of the business climate, a training project and a development plan for new generation industrial parks, called "P2I - Integrated Industrial Platforms"; The establishment of an institutional organization capable of allowing the effective and efficient implementation of programs.

\subsection{The National Pact for Industrial Emergence (PNEI)}

The National Pesticide for Industrial Emergence (PNEI) is a program contract spanning the period 2009-2015. The program aimed to create 220,000 jobs by increasing industrial GDP by DH 50 billion and generating an additional export volume of DH 95 billion. This pact also provided for 50 billion private investments in industrial activity. It required funds in the order of 12.4 billion $\mathrm{DH}$, of which $34 \%$ were dedicated to training and human resources and $24 \%$ to investment incentives. The National Pact for Industrial Emergence aims to build a competitive and productive industry, it focuses on the World Trades of Morocco (MMM): automotive, aeronautics, electronics, Offshoring, textile and agribusiness. The latter are divided into two categories: Foreign Direct Investments (FDI) oriented trades This category includes Offshoring, Automotive, Aeronautics and Electronics. These businesses will benefit, as part of this program, from the creation of 22 integrated industrial platforms (P2I) which are reception sites for investors. Regarding the second category of MMM, it is represented by the traditional trades namely: the textile-leather and agro-food sector. For the textile-leather sector, the state provides support for international marketing. At the same time, dedicated logistics areas will be created and tariff reforms will be put in place. Agribusiness is not left out, since the State will encourage investment in value-added 


\section{INSIGHTS INTO REGIONAL DEVELOPMENT}

ISSN 2669-0195 (online) http://jssidoi.org/jesi/

2019 Volume 1 Number 2 (September)

http://doi.org/10.9770/IRD.2019.1.3(4)

sectors (citrus fruits and olive oil for example) and will support the best players in consumer products (confectionery, biscuits among others). The State will also promote integrated projects in basic commodities such as milk and meat for example. In 2012, the industry drained nearly 8 billion dirhams of foreign direct investment (FDI), or 26 percent of total FDI, which puts the sector at the forefront. Industrial GDP, meanwhile, increased by 28.4 billion dirhams between 2008 and 2011. More than 100,000 jobs were created in the global businesses of Morocco between 2009 and 2012. During the same period, the exports of the automotive sector increased by more than $125 \%$ while those of the aeronautical industry recorded an increase of $60 \%$ (MEF, 2013).

\subsection{Industrial acceleration plan}

The regression of the part of industrial GDP in the national GDP from $16.62 \%$ in 2003 to $14.57 \%$ in 2012 a decline accompanied, of course, a loss of industrial jobs as well as a decline in industrial exports, symptomatic of a loss speed in terms of competitiveness and an alarming deindustrialisation. The Industrial Acceleration Plan aims to increase the share of industrial GDP in the national GDP from $14 \%$ to $23 \%$ by 2020 as well as the creation of 500,000 jobs over the next ten years. This plan was accompanied by the creation of an Industrial Investment Fund (FDI) with a budget envelope of 20 billion dirhams (approximately 1.835.000.000,00 Eur) over 7 years. FDI grants and subsidies will be conditional on employment generated, value creation and export volumes. The plan also plans to support the productive actors who move in the dark to the formal, by creating the status of the self-entrepreneur and the support to VSEs through an appropriate tax and other measures to facilitate its integration in the economic fabric. Another measure put in place by the Industrial Acceleration Plan is the development of industrial ecosystems following the logic of "industrial development-territorial competitiveness" which was introduced with the first P2I. The aim is to reduce the fragmentation of the industrial sector, build a more integrated and less fragmented industrial fabric, while allowing SMEs to benefit from strategic alliances with large companies through economic interest groups. Economic interest groupings are gatherings of companies, particularly SMEs, around a large company (national business leaders, professional associations or foreign investors) which will serve as a driving force in a given sector.

\subsection{The context of creation of Integrated Industrial Platforms (P2I)}

The country's farming and industrial policies are designed to target the European market. In terms of cooperation, four strategic sectors have been identified: agro-food, textile, ICT and electronics, as well as renewable energies (Šimelyte, A. Et al, 2016). Integrated Industrial Platforms (P2I) are the result of a desire to develop the World Trade of Morocco (WTM) is an integrated vision of territorial development and the national economy, the P2I allows the industrial upgrading of the country by the involvement of the public and private sector, as is the case for the PNEI in general. The value proposition of P2I to investors revolves around the following dimensions: 1) real estate offer: rental / sale of raw surfaces or ready-to-use buildings at competitive prices; 2) offer of service on area: meeting the main needs of investors and their employees (general services, operating, business, etc.); 3) onestop administrative: grouping the key services of the State for investors; 4) zone training offer creation of a specialized institute of training or a public training center, adapted logistics offer. Optimal logistic connectivity of the area to the main national transport axes and offer of logistics services on an integrated zone, living environment and integration to the city, selection of well positioned and connected land public transport networks. 


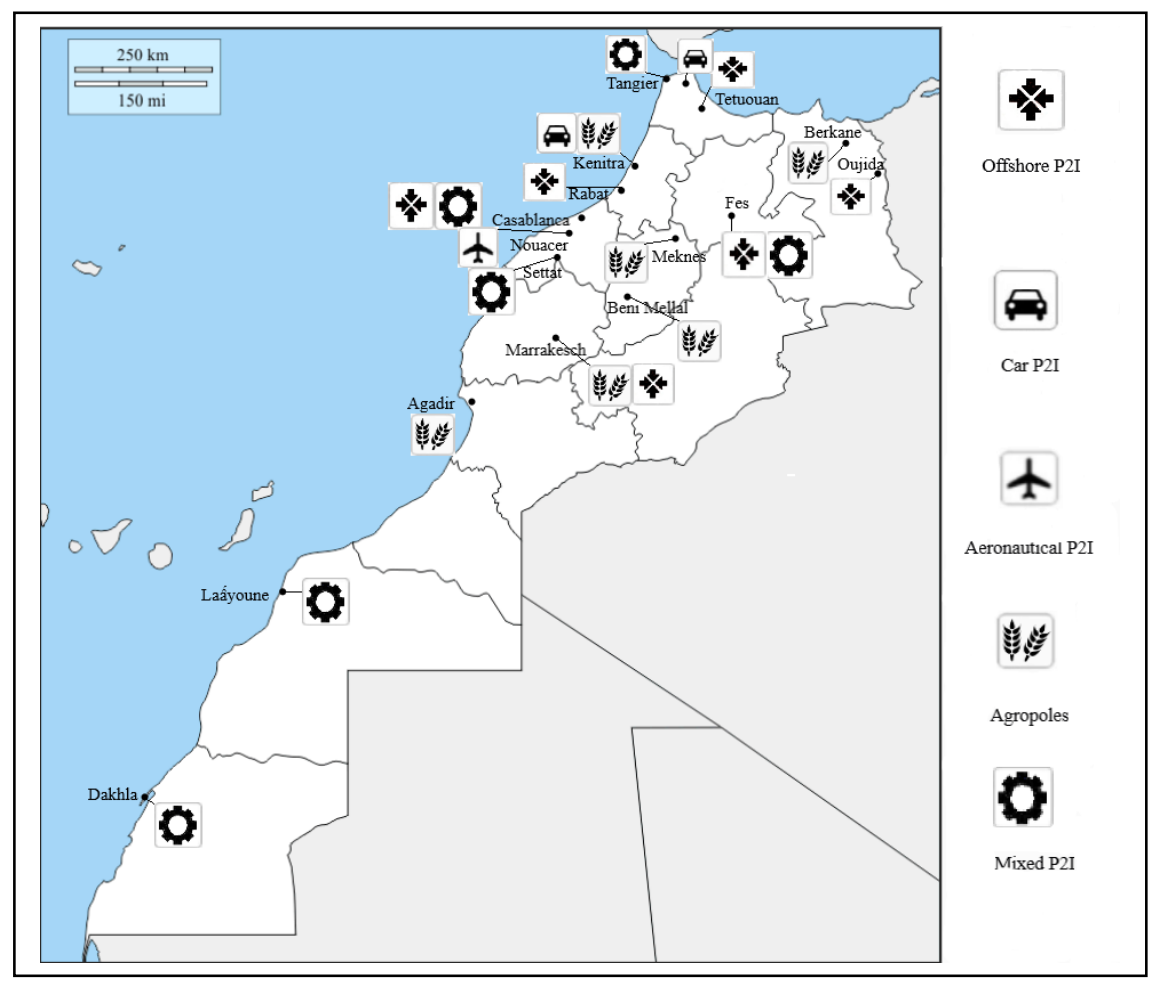

Figure 1. Integrated industrial platforms for geographical distribution Source: The Ministry of Industry, Trade, Investment and Digital Economy (2016)

Technopole of Oujda: the project of the Oujda Technopole, the first P2I launched under the program-contract, is a project specifically dedicated to the activities of manufacturing renewable energy equipment and aimed at developing a Morocco offer for solar-related activities. wind energy and energy efficiency. MEDZ, pursuing its mission of privileged partner of the public authorities for the territorial development, is in charge of the realization of this project within the framework of a partnership with the Ministry of Finance, the Ministry of Industry, the Ministry of the Energy, the Ministry of National Education, the Wilaya, the Oriental Region, the Agency of Oriental and ONDA.

Atlantic Free Zone (AFZ): AFZ, the first sectoral P2I targeting mainly the automotive sector, enjoys a strategic position, between two important economic centers, Casablanca and Tangiers. Indeed, the project spread over 345 hectares, is located $12 \mathrm{~km}$ east of the city of Kenitra (Gharb Chrarda Bni Hssen) and enjoys excellent connectivity (rail, air and highway). The figure 1 shown the integrated industrial platforms.

The industrial sector, the second largest employer at the national level as shown in figure 2 below, employs $12.7 \%$ of the labor force. Trade and "general administration and social services provided to the community" occupy respectively $12.5 \%$ and $10.2 \%$ of this population. This sectoral distribution, maintained since 2000 , reflects the sectoral stability of employment at national level (Ministry of Economy and Finance in Morocco DEPF, 2009). In addition, the agriculture, fishing and forestry sector is the main source of activity with $42.1 \%$ of the labor force. In the industrial sector, the dominant sectors are textile-clothing (Tangier, Casablanca, Guercif and Taza), mechanical and electrical subcontracting (Casablanca) and information and communication technologies. The textile-clothing industry has some advantages. 


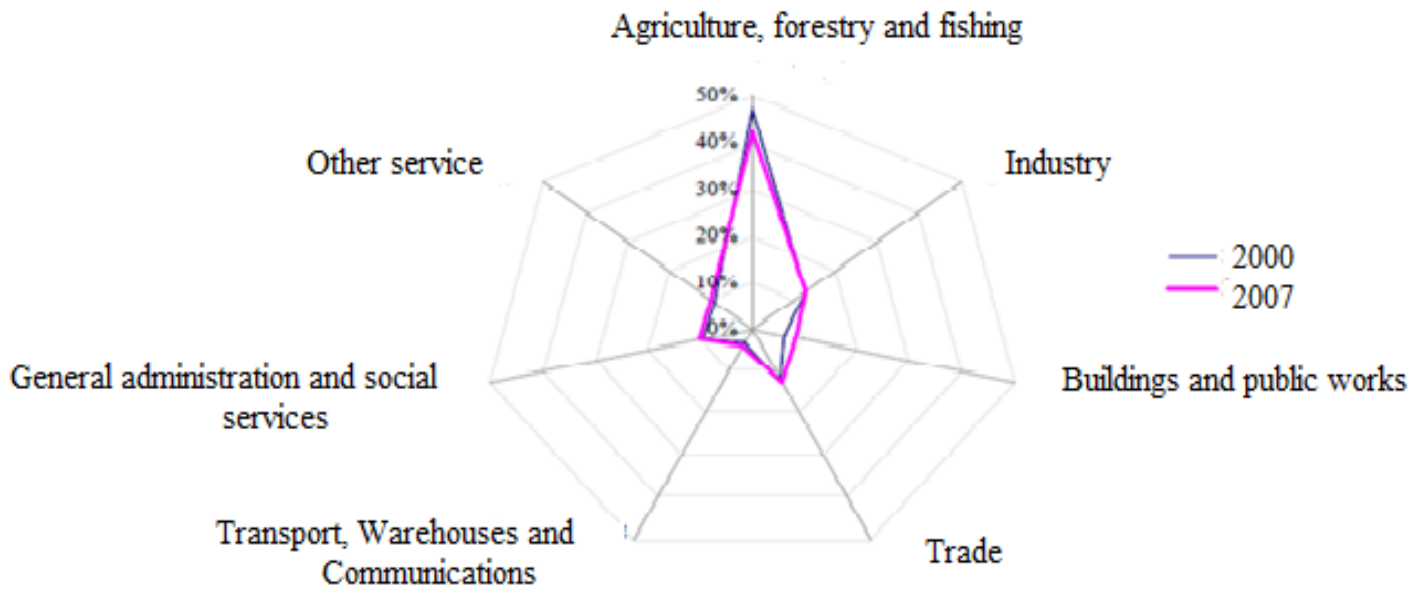

Figure 2. Evolution of the employment structure by branch of economic activity. Source: The Ministry of Economy and Finance of Morocco (2008)

In fact, SMEs and SMIs represent more than $85 \%$ of the industrial fabric of the sector (Bakala, 2017). In the FezMeknes region, it is the leather, brassware and tourism sectors in the Ziz valley. A study by the Directorate of Studies and Financial Forecasts (DEPF) converged on the same observation, namely a high concentration of industrial employment in labor-intensive industries such as the clothing industry (32\%) and the food industries (16\%) (Pommier, 2014).

\section{Emergence and development of clusters in Morocco}

The globalization of economies and the restructuring of the industrial sector have made it possible to strengthen the presence of SMEs / SMIs internationally as a guarantee of competitiveness, innovation and flexibilityflexibility. A requirement also for Morocco especially that its productive fabric is $93 \%$ of the SME / SMI, in addition the application of the networking between the intelligent territories, such a process generates the inter connectivity between local productive system SPL and clusters sheltering clusters of flexible entities pooling the risks and costs of strategic operations (Bouayad et al, 2008). Cluster-type organizations are well-rooted in the Moroccan economy, with many small-scale enterprises and small farms having joined together in the form of cooperatives from 1937 to bring together production and joint processing of products. The form, purpose and level of support of the state have varied over time. Although they cannot be considered as "innovation clusters", cooperatives are an ever-active and relevant traditional form of clusters, which constitute high-value chains. The first analyses made on clusters go back to the beginning of the 2000s by the Directorate of Spatial Planning, which is responsible for the National Spatial Planning Scheme. Conducted by French and Moroccan academics, 


\section{INSIGHTS INTO REGIONAL DEVELOPMENT}

ISSN 2669-0195 (online) http://jssidoi.org/jesi/

2019 Volume 1 Number 2 (September)

http://doi.org/10.9770/IRD.2019.1.3(4)

statistical work and field surveys on Localized Production Systems or SPL have identified about fifty agglomerations of specialized institutions totalling 35\% of Moroccan manufacturing employment (P. Pommier, 2014). Since the 2000s, Morocco has adopted a policy of creating clusters, the state of which engages with local actors through consultation. The policy pursued by the government aims, in fact, to encourage projects to promote the agglomeration and the cooperation of the companies in several sectors and the reinforcement of the links with the local institutions as well private as public in particular, in the fields of formation and research, etc. This policy of local synergies and exchange of knowledge is at the heart of the policy of clusters proposed by the public authorities. The objective is to provide cluster companies with assistance for their joint activities and to create a global environment conducive to their development and competitiveness. Cluster development policy, which Morocco is committed to through the National Pact for Industrial emergence aimed to develop 15 national cluster initiatives in 2009.

The Moroccan cluster program (2009) now includes the "Morocco Innovation Strategy" program, which aims to improve research and development (R\&D) and promote innovation by targeting triple helix agents. Since 2009, the Maroc Innovation initiative has been aiming to create more than 200 innovative start-ups until 2014, and to register a thousand Moroccan patents. The Cluster program combines a top-down and bottom-up approach: public support and at the same time launching a competition between Clusters. Other cluster organizations are promoted by other stakeholders such as the Solar Cluster or the Industrial Services Industry Cluster (CISE). In addition, Morocco is actively pursuing an industrial policy plan ("Industrial Acceleration Plan") until 2020, which includes the development of cluster organizations and their policies. In this respect, Morocco has developed the strategy for the installation of Integrated Industrial Platforms (P2I) and Techno poles, as well as a strategy to support and label Clusters in order to create ecosystems. This economic recovery aims to develop modes of cooperation within the territories and in sectors with high potential for innovation, allow the diffusion of positive externalities and technological overflows (Ministry of Industry, Trade, Investment and Digital Economy, 2016).

\subsection{Characteristics of clusters in Morocco}

Clusters in Morocco is defined as an association constituted in accordance with Dahir No. 1-58-376 dated (November 15, 1958) as it has been completed and amended, whose members are enterprises, institutions and research center or training and institutions, operating in the industrial and technological sectors, with a common development strategy and whose statutory purpose is to stimulate the emergence of innovative collaborative projects. In addition to these traditional clusters, the Moroccan state has allowed the emergence of clusters in industrial value chains. Moroccan clusters have recently emerged on the basis of a double impulse. On the one hand, the impetus for industrial policy of grouping companies from the same sector in the same territory, either through the development of technology parks or designated free zones, has enabled Moroccan industries to same sector to regroup. This impetus was complemented by a policy led by the Ministry of Finance and titled "Moroccan Innovation" in 2009 (European cluster collaboration platform.eu, 2019). This strategy, which aimed to stimulate innovation and competitiveness, aimed specifically at creating clusters and providing public funding for this effect.

As a result, clusters in Morocco come in three different forms:

1) Agricultural / craft cooperatives: cluster initiatives, built on a model comparable to certain European clusters, an association of companies, the public sector and academics who join forces to collaborate and innovate;

2) Agropoles and Technoparc bring together industries from the same sectors in the same territory, as well as research institutes in order to foster innovation and increase the region's specialization for increased competitiveness and attractiveness:

- Agro-pôle Olivier - olives and olive oil cluster. Technology transfer and providing accessibility of international achievements for contributing to the upgrade and development of the olive sector;

- Agrinnov is a cluster gathering the agro-food stakeholder of Morocco; 
- Agrotech SMD is platform for exchange and cooperation between regional and national institutions regarding agriculture;

- Agadir Haliopôle located in a fishing area, the cluster encourage R\&D to improve to products and boosts exports. The cluster has received a Bronze ECSA label in 2014;

- Casa Technopark was launched in 2001 on the city of Casablanca. Rabat duplicated the model in 2012. Technopark Casa is a community of innovation constantly hosting more than 230 companies (Casablanca \& Rabat) in the sectors ICT and "green tech" with more than 60 new starts-up every year;

- CasaNearShore Park is a service offering office spaces and other infrastructure and assistance services to companies specialising in software development, infrastructure management, back office banking, insurance services, and customer relationship management; supporting offshoring of international enterprises;

- Parc Technopolis with an area of 300 hectares, addressing investments and projects related to new technology sectors;

- Fès Shore is dedicated to developing new economic potential of the region in the field of offshoring.

3) CleanTech cluster benefiting from the status of free zone, focused on the development mainly in the solar, wind and energy efficiency sectors.

The National Pact for Industrial emergence aimed to develop 15 national cluster initiatives in 2009, but the number of clusters labeled at the end of 2016 are 11 clusters whose target for 2020 is 20 clusters. In the table 2 regrouping different Moroccan clusters operating in different sectors and specialization (Table 2).

Table 2. Grouping different Moroccan clusters

\begin{tabular}{|c|c|c|c|c|}
\hline $\begin{array}{c}\text { Cluster/ year of } \\
\text { creation }\end{array}$ & Sector & Specialisation & Members of clusters & Region \\
\hline $\begin{array}{c}\text { Morocco Numeric } \\
\text { Cluster / } \\
\text { November } \\
2010\end{array}$ & ICT & $\begin{array}{l}\text { Mobile services, } \\
\text { security, electronic } \\
\text { banking, digital } \\
\text { rights; multimedia } \\
\text { packages. }\end{array}$ & $\begin{array}{l}\text { Ministry of Industry Trade and New Technologies: } \\
\text { ASTEC; AUSIM; APEBI; CGEM; SoftCenter; Al Jisr, } \\
\text { MITC; GreenTic, Technopolis; University Mohammed } \\
\text { V of Rabat; Hassan II University of Casablanca; } \\
\text { University Ibn Toufail of Kenitra; University Hassan } 1^{\text {st }} \\
\text { in Settat; University Sidi Mohamed Ben Abdellah of } \\
\text { Fes; CNRST; ENSA; EMSI; ENSEM; INPT. }\end{array}$ & $\begin{array}{c}\text { TechnoPark in } \\
\text { Casablanca }\end{array}$ \\
\hline
\end{tabular}


INSIGHTS INTO REGIONAL DEVELOPMENT

ISSN 2669-0195 (online) http://jssidoi.org/jesi/

2019 Volume 1 Number 2 (September)

http://doi.org/10.9770/IRD.2019.1.3(4)

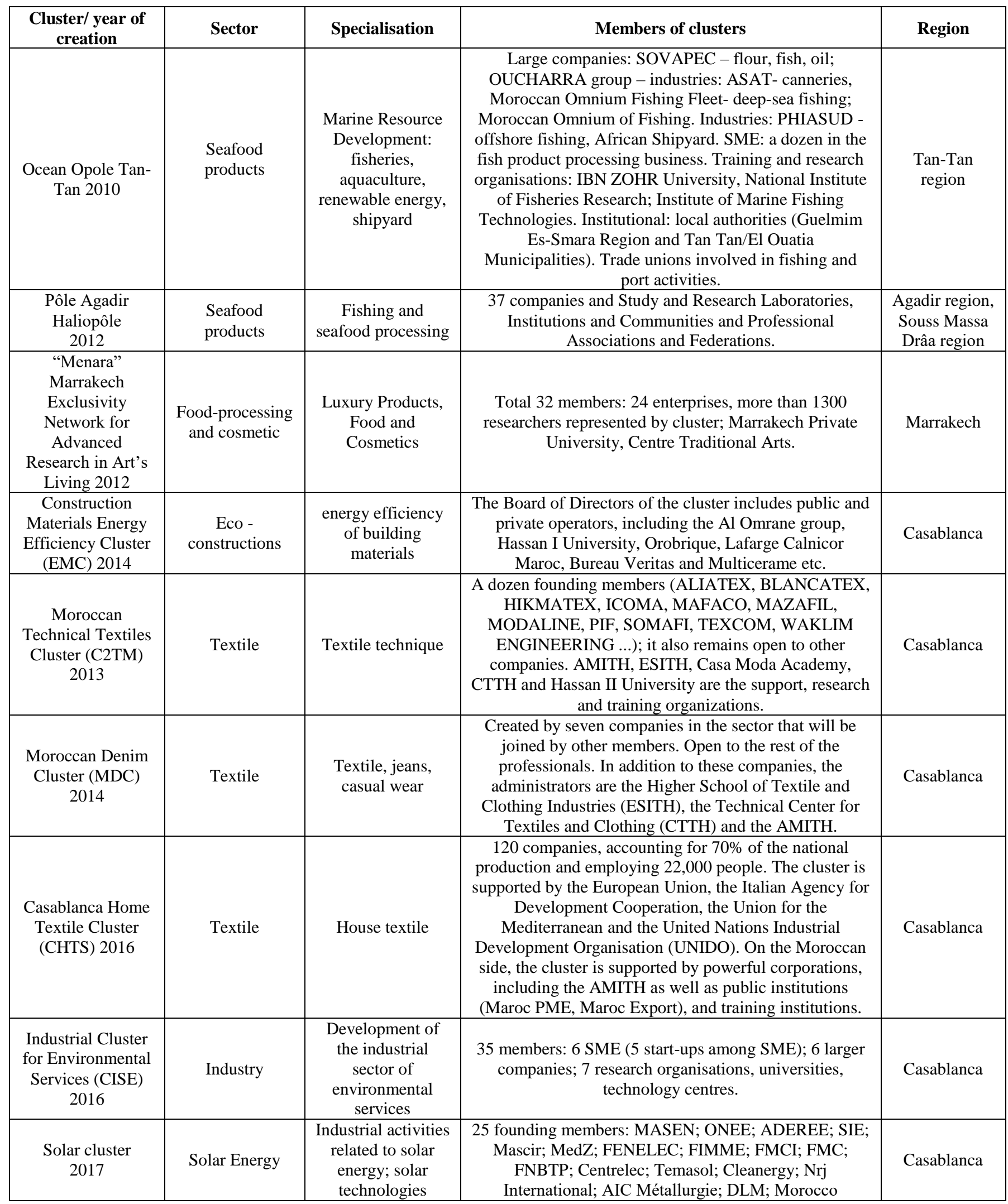


INSIGHTS INTO REGIONAL DEVELOPMENT

ISSN 2669-0195 (online) http://jssidoi.org/jesi/

2019 Volume 1 Number 2 (September)

http://doi.org/10.9770/IRD.2019.1.3(4)

\begin{tabular}{|c|c|c|c|}
\hline $\begin{array}{c}\text { Cluster/ year of } \\
\text { creation }\end{array}$ & Sector & Specialisation & Members of clusters \\
\hline & & $\begin{array}{c}\text { Workshop; LSA Industries; ADI; Cegelec; Ciments du } \\
\text { Maroc; Cadi Ayad University; Rabat International } \\
\text { University and CERIMME and fourteen other members } \\
\text { of the Board of Directors including FENELEC and } \\
\text { FIMME, five business colleges and two colleges of } \\
\text { educational organizations, higher education, vocational } \\
\text { training and research. }\end{array}$ \\
\hline $\begin{array}{c}\text { Aerospace } \\
\text { Moroccan Cluster }\end{array}$ & Aerospace & $\begin{array}{c}\text { Aerospace } \\
\text { (AMC) } 2011\end{array}$ & $\begin{array}{c}\text { 105 international companies: Anchor companies; Safran; } \\
\text { EADS; Bombardier \& Boeing; Aerotechnic industries; } \\
\text { UTC Aerospace systems; Royal Air Maroc; Air France } \\
\text { AIRBUS, Snecma Morocco Engine services. }\end{array}$ \\
\hline
\end{tabular}

Source: prepared by authors

Four strategic sectors, presenting attractive clusters, in the context of EU-Morocco cluster cooperation were identified: the agro-food industry; textile; ICT and electronics; renewable energies.

The agro-food sector is the sector in which the most diverse types of clusters can be found: small-scale farming cooperatives; two clusters; two acropoles.

\section{Innovation performance of clusters and their impacts on regional development.}

Cluster performance in innovation is a fundamental part of their existence in the literature. Several authors have shown the importance of performance measurement systems. According to L. C. R Carpinetti et al. (2007), the system for measuring the performance of a cluster is composed of the following four categories:

1) economic and social outcomes: economic growth, gross product and employment as the main indicator of the size of the cluster (Smith et al., 2006);

2) business performance: growth and competitiveness (productivity, costs, benefits ...), triggered by easier access to valuable resources and services;

3) collective efficiency: cooperation actions, including innovations and spin-offs;

4) social capital: cultural values such as trust and cooperation.

The indicators for measuring the performance of a cluster according S. Chalaye, N. Massard (2009) are: the position of firms in the cluster vis-à-vis global competition (global market penetration capacity, market share), the number of common projects, the replacement rate of failing firms, the level of exports of members. Cluster performance measures can also be performed across the number of firms in a given location (Krugman, 2012). According to S. Chalaye, N. Massard (2009), the determinants of the clusters are a structural nature of the functioning of the cluster (economic, geographical or governance order), the determinants linked to the potential of R\&D, the capacity of the cluster to transform these resources into innovations, the positioning of the cluster in terms of sectors and markets, the level of cluster connectivity, and the cluster environment.

Moreover, some authors argue, the life cycle of clusters depends on four phases of development in the emergence of the cluster: diffusion; commercialization and decline of a technology; the development cycle of the industry (Favoreu et al., 2008).

The Morocco Microelectronics Cluster (MMC) uses the following indicators: networking and partnerships: number of partnerships signed, number of cooperation protocols signed, number of network events, number of joint R\&D, innovation and technology transfer activities (El malki, 2012). In this respect, according to a study carried out on six Moroccan clusters, with different activities, the number of labelled cluster companies is 252 companies, or an average of 39 enterprises per cluster. SMEs represent $66.37 \%$ of these companies: large 


\section{INSIGHTS INTO REGIONAL DEVELOPMENT}

ISSN 2669-0195 (online) http://jssidoi.org/jesi/

2019 Volume 1 Number 2 (September)

http://doi.org/10.9770/IRD.2019.1.3(4)

companies $=2$ SMEs. In cluster 2, SMEs account for 91.48\%. Half of the six clusters are home to fewer than 30 companies the other three clusters have more than $70 \%$ of the business population of all clusters (El Waatmani, Makhtari, 2019), see Table 3.

Table 3. Number of companies by cluster.

\begin{tabular}{|c|c|c|c|c|c|c|}
\hline Number of companies by cluster & Cluster 1 & Cluster 2 & Cluster 3 & Cluster 4 & Cluster 5 & Cluster 6 \\
\hline SMEs & 30 & 43 & 10 & 45 & 17 & 9 \\
\hline Large companies & 20 & 4 & 10 & 20 & 10 & 14 \\
\hline Total companies & 50 & 47 & 20 & 65 & 27 & 23 \\
\hline
\end{tabular}

Source: author based on A. El Waatmani, M. Makhtari (2019).

The entrepreneurial performance of clusters is measured by the number of start-ups created within the clusters, the total number of start-ups amounts to 60 start-ups on average 10 start-ups per cluster, which proves that the development of start-ups depends on the investment cost. In addition, innovative collaborative projects are an important indicator, since the presence of educational and research institutions is the cornerstone of innovation, there are 127 innovative collaborative projects on average of 21 projects per cluster. As a consequence, there are 25 patents filed by the six clusters studied an average of 4 patents per cluster (El Waatmani, Makhtari, 2019).

In addition, public authorities launch calls for projects from clusters, operating in the industrial and / or technological sectors, carrying a significant development strategy for their sectors and for which innovation is a central factor in competitiveness. Innovation and $R \& D$, which puts the clusters into question, the difficulties they face vis-à-vis the objectives drawn by the public authorities at the level of the policy of support for clusters and the strategies traced "Maroc innovation" the creation of start-ups and patent filings. The performance of clusters depends on several factors: the sector in which it operates (ICT) or textile, the degree of dynamism of the cluster's leadership team, the governance within the cluster, the human resources in charge of management of clusters and their managerial capacities. The Moroccan Court of Auditors (2014) conducted an evaluation of the "Maroc Numeric 2013: MN2013" strategy concerning its governance and management and the assessment of the achievement of the objectives of the strategy through the analysis of its indicators and indicators. International ICTs. The report was organized around different themes: social transformation, implementation of user-oriented public services, computerization of SMEs, development of the ICT industry. Strategies accompanied by actions for the development of human capital and digital trust. According to the Court, most of the objectives have not been met and far from it with achievement rates ranging from only $10 \%$ to 50\%. Among other things, only $10 \%$ of the 3,000 pilot SMEs that need to be computerized in the context of the Moussanada IT program have actually been computerized (Moroccan Court of Auditors, 2014).

In general, research and innovation in Morocco is poorly structured and lacks homogeneity between the various stakeholders (Universities, National Center for Scientific and Technical Research (CNRST) and specific entities corresponding to a given sector (National Institute of Agronomic Research (INRA), National Institute of Posts and Telecommunication (INPT), etc.) According to the Economic, Social and Environmental Council or (CESE) report (2014), the low budgets allocated to research and innovation, which went from 0.4\% of GDP in 1999 to $0.8 \%$ of GDP in 2013, show that the system suffers from a weakness in scientific production. With a global share of Morocco of $0.12 \%$ in 2010, the national private productive sector considers itself to be self-employed in terms of applied research and innovation and is rarely organized or structured: between 2009 and 2010. In a sample of 300 Moroccan companies, only $23 \%$ of them reported having an R\&D and innovation activity, and the number of national patents per million inhabitants improved from 152 in 2010 to 353 in 2014. The number of patents filed with foreign participants was 855 in 2010 and 743 in 2014. By region, the figures show the predominance of the 


\section{INSIGHTS INTO REGIONAL DEVELOPMENT}

ISSN 2669-0195 (online) http://jssidoi.org/jesi/

2019 Volume 1 Number 2 (September)

http://doi.org/10.9770/IRD.2019.1.3(4)

Greater Casablanca region in terms of enterprises created, national industrial production, industrial exports and staff employed during the period 1985-2014, with a rise in Tangier-Tetouan region in recent years.

\section{Conclusion}

The recent industrial development experienced by Morocco through the establishment of three plans (Emergence Plan, National Pact of Industrial Emergence, Industrial Acceleration Plan) to make its productive system more competitive and innovative has given birth to clusters by the initiative of the government, as in other countries, the emergence of innovative market-oriented projects and support companies and the most voluntarist actors to build high-level clusters. The effectiveness and performance of Moroccan clusters suffers from governance and adaptation to the regional, national and international context, it is necessary to integrate other competitive factors of Moroccan companies as the human factor whose innovation is closely linked with 'index of human development. Moreover, the managerial, financial and administrative obstacles. Lack of public and private sector partnerships and the lack of innovative collaborative projects. In this respect, Morocco must develop strong "competitive" advantages rather than "comparative" advantages in its industrial branches, through the promotion of research and development in the industrial productive system. To overcome its difficulties, it is essential to have the combination of knowledge to innovation and to develop specializations to be able to capture advanced knowledge produced from a distance, to assimilate and exploit them and to encourage collaboration between EUMorocco clusters.

\section{References}

Aligod, L. (2016). Dynamique et performance des clusters en innovation: quel impact sur le développement économique des territoires d'implantation //Thèse du Doctorat en Sciences Economiques et Gestion, faculté des sciences juridiques économiques et sociales Fès, p.1301.

Amine, R. (2016). Les clusters au Maroc : vers l'émergence d'une nouvelle politique industrielle territoriale, Marché et organisations 2(26) : 93-120.

Bakala, H. (2017). La politique des clusters au Maroc quel avantage pour le secteur de textile-habillement, Revue Interdisciplinaire 1(3) : 7. Available online: https://odd.hcp.ma/file/76512

Bouayad, A., Eddelani, O. (2008). Cluster: écosystème d'innovation, incubateur d'organisations compétitives et de territoires intelligents (cas de Fès-Boulmane au Maroc). P. 1

Callegati, E., Grandi, S. (2007). Cluster dynamics and innovation in SMEs: the role of culture. Available from URL:http://www.eblacenter.unito.it/WP/2005/3_WP_Ebla.pdf.

Carpinetti, L.C. R.; Gerolamo, M.C., Galdámez, E.V.C. (2007). Continuous innovation and performance management of SME clusters, Creativity and Innovation Management 16(4): 376-85.

Chalaye, S., Massard, N. (2009). Les clusters : Diversité des pratiques et mesures de performance, Revue d'économie industrielle [En ligne], 128 | 4e trimestre, document 7, mis en ligne le 01 décembre 2011. https://doi.org/10.4000/rei.4079

Cour Des Comptes. (2014). Evaluation de la stratégie Maroc Numéric 2013, Rapport particulier n05/13/CHIV. PP 13.

Delgado, Mercedes \& E Porter, Michael \& Stern, Scott. (2014). Defining Clusters of Related Industries, Working paper series (National Bureau of Economic Research). https://doi.org/10.1093/jeg/lbv017

Eddelani, O., El Idrissi, N. E., Monni, S. (2019). Territorialized forms of production in Morocco: provisional assessment for an own model in gestation, Insights into Regional Development 1(1): 6-18. March. https://doi.org/10.9770/ird.2019.1.1(1)

EL Malki, Z. (2012). Présentation du cluster MNC. 


\section{INSIGHTS INTO REGIONAL DEVELOPMENT}

ISSN 2669-0195 (online) http://jssidoi.org/jesi/

2019 Volume 1 Number 2 (September)

http://doi.org/10.9770/IRD.2019.1.3(4)

El Waatmani, A., Makhtari, M. (2019). Déterminants et mesure de la performance des clusters : un aperçu sur le modèle Marocain, Moroccan Journal of Entrepreneurship, Innovation and Management [S.1.], v. 3, n. 2, p. 77-89, jan. 2019. ISSN 2509-0429. https://revues.imist.ma/index.php?journal=RMEIM\&page=article\&op=view\&path\%5B \%5D=14964.

European cluster collaboration platform.eu.( 2019). D.3.2- Preparatory Briefing on Morocco // https://www.clustercollaboration.eu/sites/default/files/eccp_d3.2_preparatory_briefings_morocco_v1.2_20190108.pdf

Favoreu, C., Lechner, C., Leyronas, C. (2008). Légitimité des politiques publiques en faveur des clusters, Revue française de gestion. Lavoisier 3(183): 157-178.

Gallié, E., Glaser, A., Pallez, F. (2014). Une analyse comparative des évaluations de politiques de clusters en Europe : vers deux modèles idéal-typiques, Politiques et Management Public 31(1): 87-111.

Havierniková, K., Kordoš, M. (2019). Selected risks perceived by SMEs related to sustainable entrepreneurship in case of engagement into cluster cooperation, Entrepreneurship and Sustainability Issues 6(4): 1680-1693. http://doi.org/10.9770/jesi.2019.6.4(9)

High Commission for Planning (HCP). (2009). Réformes économiques et sociétales au Maroc Quelques données et indicateurs sur la croissance et le développement humain.

https://revues.imist.ma/index.php?journal=RMEIM\&page=article\&op=view\&path\%5B\%5D=14964.

Krugman, P. (1990). Increasing returns and economic geography, National Bureau of economic research. https://www.nber.org/papers/w3275.pdf

Ministry of Foreign Affairs and International Cooperation. (2019). Plan émergence 2020//

https://www.diplomatie.ma/Portals/12/index_test/localhost/diploslack/10.html

Ministry of Economy and Finance of Morocco. (2009). Spécialisation et concentration industrielles Atouts et vulnérabilités des secteurs et des régions // Direction des Etudes et des prévisions financières. Available online:

https://www.finances.gov.ma/Docs/depf/2009/4416_concentrationetspecialisation.pdf

Ministry of Economy and Finance of Morocco (2009). Concentration et spécialisation, Direction des Etudes et des prévisions Financière.

Ministry of Economy and Finance of Morocco (2015). Situation et perspectives de l'économie nationale : Au-delà de l'écran comptable, la transformation structurelle continue // Direction des Etudes et des prévisions Financière. P. 4. Available online:

https://www.finances.gov.ma/Docs/dtfe/2015/etude ecrancomptabletransformation.pdf.

Ministry of Economy and Finance of Morocco (2018). Synthèse du Rapport Economique et Financier 2018 // Direction des Etudes et des prévisions Financière, P.1 Available online:

https://www.finances.gov.ma/Docs/DB/2017/Synthese\%20\%20REF\%202018_10\%2001\%202018.pdf

Ministry of Economy and Finance of Morocco (2009). Spécialisation et concentration industrielles Atouts et vulnérabilités des secteurs et des régions// Direction des études et prévision financière.

Ministry of Economy and Finance of Morocco (2013). Pacte National pour l'Emergence Industrielle // Investissement. Available

online:https://www.finances.gov.ma/fr/pages/strat\%C3\%A9gies/pacte-national-pour-

$\underline{1 \% \mathrm{E} 2 \% 80 \% 99 \text { emergenceindustrielle.aspx?m=Investisseur \&m2=Investissement }}$

Ministry of Industry, Trade, Investment and Digital Economy of Morocco (2016). Industrial Acceleration Plan //

http://www.mcinet.gov.ma/en/content/industrial-acceleration-plan-2014-2020

Monni, S., Palumbo, Tvaronavičienè, M. (2017). Cluster performance: an attempt to evaluate the Lithuanian case, Entrepreneurship and Sustainability Issues 5(1): 43-57. http://doi.org/10.9770/jesi.2017.5.1(4)

Parto, P. (2008). Innovation and economic activity: an institutional analysis of the role of clusters in industrializing economies, Journal of Economic Issues, 1005-1030.

Petrenko, Y., Vechkinzova, E., Antonov, V. (2019). Transition from the industrial clusters to the smart specialization of the regions in Kazakhstan, Insights into Regional Development 1(2): 118-128. https://doi.org/10.9770/ird.2019.1.2(3) 
INSIGHTS INTO REGIONAL DEVELOPMENT

ISSN 2669-0195 (online) http://jssidoi.org/jesi/ 2019 Volume 1 Number 2 (September) http://doi.org/10.9770/IRD.2019.1.3(4)

Pommier, P. (2014). Clusters au Maghreb Vers un modèle de cluster maghrébin spécifique // institut de prospective économique du monde méditerranéen, ipemed. Available online: http://www.ipemed.coop/adminIpemed/media/fich_article/1411461804_IPEMED\%20\%20Clusters\%20au\%20Maghreb.pdf.

Porter, M. (1990). The Competitive Advantage of Nations. New York: The Free Press.

Porter, M. (1998). Clusters and the new economy of competition, Harvard Business Review 6(6): 77-91.

Šimelyte, A.; Ševčenko, G.; El Amrani El Idrissi; N., Monni, S. 2016. Promotion of renewable energy in Morocco, Entrepreneurship and Sustainability Issues 3(4): 319-327. http://dx.doi.org/10.9770/jesi.2016.3.4(2)

Smith, D., Ibrahim, G. (2006). Cluster dynamics: Corporate strategy, industry evolution and technology trajectories-a case study of the East Midlands aerospace cluster, Local Economy 21(4): 362-377.

Staber, U. (2001). Spatial Proximity and Firm Survival in a Declining Industrial District: The Case of Knitwear Firms in Baden-Wu" rttemberg, Regional Studies 35(4): 329-341.

Torre, A., Zimmermann, J. B. (2015). Des clusters aux écosystèmes industriels locaux, Revue d'économie industrielle, 152 4e trimestre.

Tvaronavičienė, M., Razminienė K. (2017). Towards competitive regional development through clusters: approaches to their performance evaluation, Journal of Competitiveness 9(4): 133 - 147, https://doi.org/10.7441/joc.2017.04.09

Tvaronavičienè, M., Razminienè, K., Piccinetti, L. (2015). Cluster efficiency study through benchmarking, Entrepreneurship and Sustainability Issues, 3(2): 120-127. https://doi.org/10.9770/jesi.2015.3.2(0)

Zemlickienė, V., Mačiulis, A., Tvaronavičienè, M. (2017). Factors impacting the commercial potential of technologies: expert approach, Technological and Economic Development of Economy 23(2): 410-427 http://dx.doi.org/10.3846/20294913.2016.1271061

Žižka, M., Hovorková Valentová, V., Pelloneová, N., Štichhauerová, E. (2018). The effect of clusters on the innovation performance of enterprises: traditional vs new industries. Entrepreneurship and Sustainability Issues 5(4): 780-794. http://doi.org/10.9770/jesi.2018.5.4(6)

Yang, J., Černevičiūtè, J. (2017). Cultural and Creative industries (CCI) and sustainable development: China's cultural industries clusters, Entrepreneurship and Sustainability Issues 5(2): 231-242. http://doi.org/10.9770/jesi.2017.5.2(6)

\section{Aknowledgements}

This research was supported by the projects, which have received funding from the European Union: International Research Staff Exchange Scheme (IRSES) FP7-PEOPLE-2012-IRSES, Grant Agreement Number 319017 SHuMED and ES H2020MSCA-RISE-2014 CLUSDEVMED Grant Agreement Number 645730730
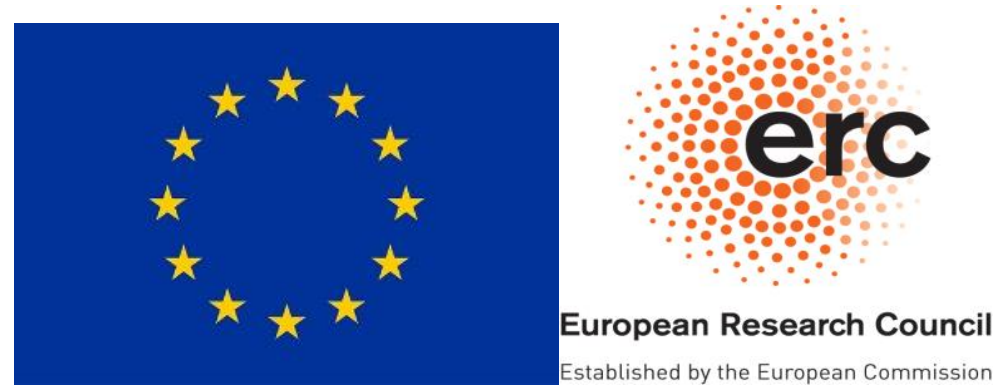
INSIGHTS INTO REGIONAL DEVELOPMENT

ISSN 2669-0195 (online) http://jssidoi.org/jesi/ 2019 Volume 1 Number 2 (September)

http://doi.org/10.9770/IRD.2019.1.3(4)

Boumediene AMRAOUI

https://orcid.org/0000-0001-5461-2721

Abdesselam OUHAJJOU

https://orcid.org/0000-0002-9613-8973

Salvatore MONNI

http://orcid.org/0000-0002-6326-5714

Najiba EI Amrani EL IDRISSI

https:// orcid.org/0000-0001-5603-1306

Manuela TVARONAVIČIENĖ

https://orcid.org/0000-0002-9667-3730

Register for an ORCID ID:

https://orcid.org/register

Copyright (C) 2019 by author(s) and VsI Entrepreneurship and Sustainability Center

This work is licensed under the Creative Commons Attribution International License (CC BY).

http://creativecommons.org/licenses/by/4.0/

c) (i) Open Access 